\title{
Tropical grass growth functions modeling by using a non-linear mixed model
}

\author{
A. HERNÁNDEZ GARAY ${ }^{1}$, H. VAQUERA HUERTA ${ }^{1}$, M. CALZADA MARÍN ${ }^{1}$, E. ORTEGA JIMÉNEZ ${ }^{1}$ AND \\ J.F. ENRÍQUEZ QUIROZ ${ }^{2}$ \\ ${ }^{1}$ Colegio de Postgraduados, Mexico. www.colpos.mx \\ ${ }^{2}$ INIFAP, Mexico. www.inifap.gob.mx
}

Keywords: Pennisetum hybrid, data analysis, pasture yield, plant components.

\section{Introduction}

Non-linear growth curves are used for modeling plant physiological variables. Agronomists often use nonlinear curves to fit data of plant growth because, unlike the coefficients of polynomials, their parameters can have biological meaning. The change in the parameters of curves fitted to data from measurements repeated over time can show how they are affected by environmental changes. The linear model approach improperly estimates the error terms when there are repeated measurements in experiments. We therefore used a maximum likelihoods approach coupled with Bayesian statistics, using a tropical cut-and-carry grass as an example.

\section{Methods}

An experiment was conducted at the experimental site "Papaloapan" of the National Institute for Agriculture, Forestry and Livestock (INIFAP), located in Isla, Veracruz, Mexico $\left(18^{\circ} 06^{\prime} \mathrm{N}, 95^{\circ} 31^{\prime} \mathrm{W} ; 65 \mathrm{~m}\right.$ asl). The climate is hot and subhumid, with rainy summers and an average annual rainfall of $1,000 \mathrm{~mm}$, and average temperature of $25.7^{\circ} \mathrm{C}$ (Enríquez-Quiroz and Romero-Mora 1999).

The experiment was established in July 2011 and the assessments were made from August 24, 2011 to January 23,2012 . A forage stand of the Pennisetum hybrid cv. Maralfalfa was harvested at different stages (different subplots) of growth $[30,60,75,90,105,120,135$, 150,165 and 180 days after planting (DAP)] and morphological components of the grass (leaf, stem, dead material) and sward height were measured. Plot size was $5 \times 16 \mathrm{~m}$.

We used non-linear models by NLMIXED procedures

Correspondence: A. Hernández Garay, Colegio de Postgraduados, Carretera México-Texcoco km 36.5, Montecillo, Texcoco 56230, Estado de México, Mexico.

Email: hernan@,colpos.mx in SAS, and a Bayesian approach with WINBUGS software for estimating the growth curve. We used a multiple non-linear growth function to model, and assumed that the response variable followed a multivariate normal distribution. A comparison of biologically relevant coefficients and the estimated standard error, and measures of adjustment were obtained. The results showed a clear advantage of non-linear mixed models over linear mixed models. The proposed model for the response variable (y) is a hierarchical normal distribution with mean $\mu(t)$ and variance $\sigma^{2}$, where

$$
\mu(t)=\frac{a}{1+b e^{-c t}}+\varepsilon
$$

the elements of the mean $\mu(t): a, b, c$ are parameters, $t$ is the time variable, and $\varepsilon \sim n\left(0, \sigma_{e}^{2}\right)$.

\section{Results}

The estimated growth curve parameters are presented in Table 1, the growth dynamics of total plant mass, morphological components (leaf, stem) and sward height are shown in Figure 1. Overall, total plant mass, and leaf and stem increased slowly during days $0-60$, after which rate of growth accelerated from day 61 to day 150 and then decreased almost to zero as growth was counteracted by increase in dead material.

\section{Conclusion}

The non-linear mixed logistic model gives a good fit for the growth of the tropical forage grass Pennisetum hybrid cv. Maralfalfa, for each of the growth components. This curve suggests that the best time to harvest this grass is at 150 days [corresponding to the inflection point of the derivative of equation (1)] if the aim is to maximize total dry matter production.

\section{References}

Enríquez-Quiroz JF; Romero-Mora J. 1999. Tasa de crecimiento estacional a diferentes edades de rebrote de 16 ecotipos de Brachiaria spp. en Isla, Veracruz. Agrociencia 33:141-148. 
Table 1. Estimated parameters of growth curves under the model, for cumulative herbage mass $(\mathrm{kg} \mathrm{DM} / \mathrm{ha})$, cumulative leaf mass (kg DM/ha), cumulative stem mass (kg DM/ha) and sward height $(\mathrm{cm})$ of Pennisetum hybrid cv. Maralfalfa.

\begin{tabular}{lllllllll}
\hline & \multicolumn{2}{l}{ Total herbage mass } & \multicolumn{2}{c}{ Leaf mass } & \multicolumn{2}{c}{ Stem mass } & \multicolumn{2}{c}{ Sward height } \\
\hline Parameter & Estimate & $\begin{array}{l}\text { Standard } \\
\text { Error }\end{array}$ & Estimate & $\begin{array}{l}\text { Standard } \\
\text { Error }\end{array}$ & Estimate & $\begin{array}{l}\text { Standard } \\
\text { Error }\end{array}$ & Estimate $\begin{array}{l}\text { Standard } \\
\text { Error }\end{array}$ \\
\hline$a$ & 37.2552 & 2.8047 & 7.4043 & 0.7344 & 25.9946 & 1.7894 & 2.4227 & 0.06972 \\
$b$ & 336.01 & 383.7 & 33.9985 & 28.0675 & 852.21 & 1182.94 & 12.7706 & 4.7777 \\
$c$ & 5.2302 & 1.1168 & 3.7793 & 1.0138 & 6.029 & 1.3138 & 4.369 & 0.636 \\
$R^{2}$ & 0.95 & & 0.94 & & 0.95 & & 0.99 & -3.6 \\
$A^{1} C^{1}$ & 195.0 & & 111.0 & & 175.1 & & 0.0414 \\
$M^{1}$ & 30.9621 & & 1.8837 & & 15.9621 & & \\
\hline
\end{tabular}

${ }^{\mathrm{T}} \mathrm{AIC}=$ Aiakaike Information Criterion, MSE $=$ Mean Square Error.

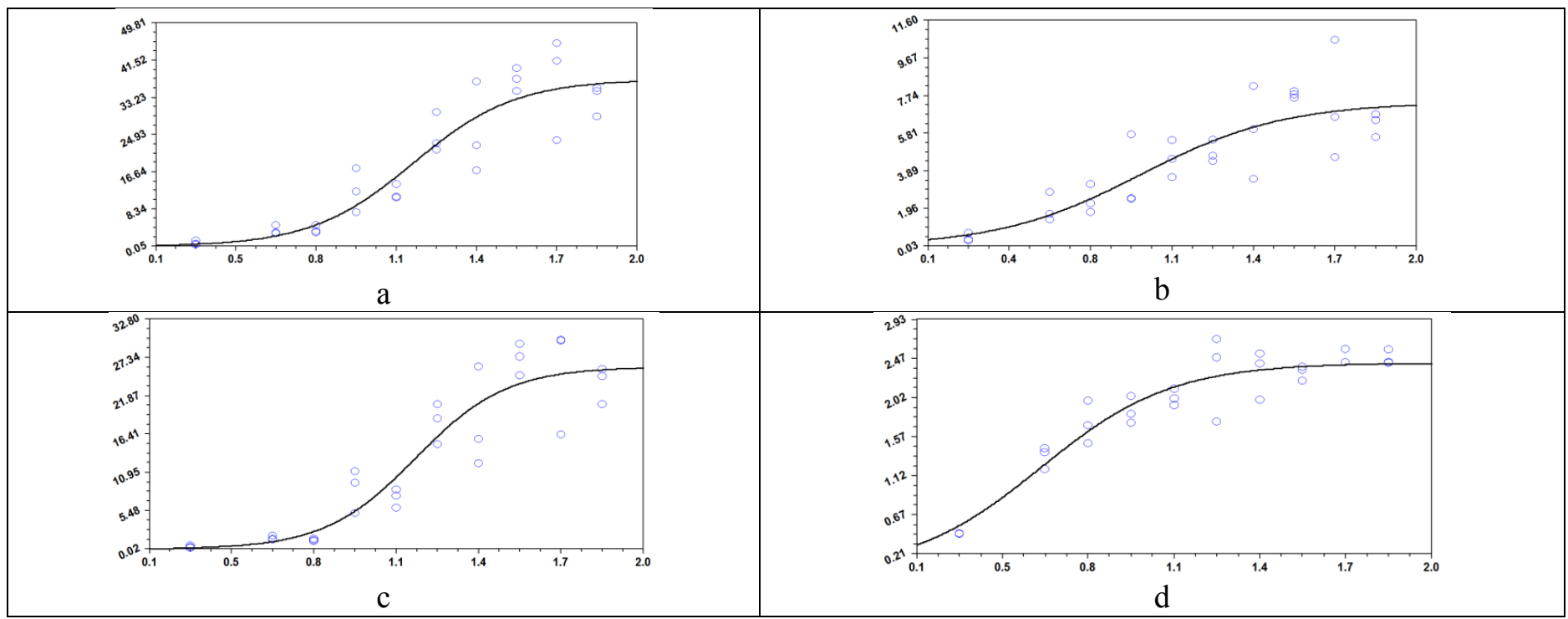

Figure 1. Growth curves for the variables, a) total cumulative herbage mass (t DM/ha); b) cumulative leaf mass (t DM/ha); c) cumulative stem mass (t DM/ha); and d) sward height $(\mathrm{m})$ of Pennisetum hybrid cv. Maralfalfa. The horizontal axis is time in days $\mathrm{x} 100$.

\section{(c) (i) (2)}

Tropical Grasslands-Forrajes Tropicales is an open-access journal published by Centro Internacional de Agricultura Tropical (CIAT). This work is licensed under a Creative Commons Attribution-NonCommercial-ShareAlike 3.0 Unported License. To view a copy of this license, visit http://creativecommons.org/licenses/by-nc-sa/3.0/. 
Hernández Garay A; Vaquera Huerta H; Calzada Marín M; Ortega Jiménez E; Enríquez Quiroz JF. 2013. Tropical grass growth functions modeling by using a non-linear mixed model. Tropical Grasslands - Forrajes Tropicales 1:90-91.

DOI: $\underline{10.17138 / T G F T(1) 90-91}$

This paper was presented at the $22^{\text {nd }}$ International Grassland Congress, Sydney, Australia, 15-19 September 2013. Its publication in Tropical Grasslands - Forrajes Tropicales is the result of a co-publication agreement with the IGC 2013 Organizing Committee. Except for adjustments to the journal's style and format, the text is essentially the same as that published in: Michalk LD; Millar GD; Badgery WB; Broadfoot KM, eds. 2013. Revitalising Grasslands to Sustain our Communities. Proceedings of the $\mathbf{2 2}^{\text {nd }}$ International Grassland Congress, Sydney, Australia, 2013. New South Wales Department of Primary Industries, Orange, NSW, Australia. p. 215-216. 